\title{
Effects of thioridazine on mechanical responses of human vas deferens induced by noradrenaline or potassium
}

\author{
N. I. B. Amobi and I. C. H. Smith* \\ Biomedical Sciences Division, King's College London, Campden Hill Road, London W8 7AH, UK
}

\begin{abstract}
Summary. Thioridazine $\left(0 \cdot 1-10 \mu \mathrm{mol}^{-1}\right)$ inhibited shortening of specimens of human vasa deferentia induced by noradrenaline $\left(100 \mu \mathrm{moll}^{-1}\right)$ or high extracellular potassium $\left(136 \mathrm{mmol}^{-1}\right)$. Thioridazine did not inhibit the lengthening response. In $\mathrm{Ca}^{2+}$-free media with EGTA $\left(0.5 \mathrm{mmol}^{-1}\right)$ similar results were obtained with responses to noradrenaline, but exposure to potassium elicited small contractions that were potentiated by thioridazine. Both shortening and lengthening responses to noradrenaline were antagonized by the $\alpha$-adrenoceptor blockers prazosin $\left(1-10 \mu \mathrm{moll}^{-1}\right)$ and phentolamine $\left(1-10 \mu \mathrm{mol} \mathrm{l}^{-1}\right)$ and by the $\mathrm{Ca}^{2+}$ antagonists verapamil $\left(10 \mu \mathrm{mol}{ }^{-1}\right)$ and diltiazem $\left(10 \mu \mathrm{moll}^{-1}\right)$. Responses to potassium were virtually abolished by the $\mathrm{Ca}^{2+}$ antagonists. These results show that thioridazine specifically inhibits longitudinal muscle of the human vas deferens and that its action cannot be entirely accounted for by a blockade of voltage-gated $\mathrm{Ca}^{2+}$ channels.
\end{abstract}

Keywords: vas deferens; noradrenaline; potassium; thioridazine; verapamil; diltiazem; human

\section{Introduction}

Phenothiazine antipsychotic drugs produce their therapeutic action by blocking dopamine $\mathrm{D}_{2}$ receptors (Creese et al., 1976; Svendsen et al., 1988). However, the clinical use of neuroleptic drugs such as thioridazine is associated with some peripheral side effects unrelated to the blockade of dopamine receptors. For example, the sedative and hypotensive action of thioridazine is believed to be caused by the inhibition of $\alpha_{1}$-adrenoceptors (Peroutka \& Snyder, 1980; Gould et al., 1984). Its other pharmacological effects include the antagonism of processes that depend on calmodulin (Beitner et al., 1989) and blockade of histamine, serotonin and muscarinic receptors. The latter is believed to be responsible for the limited extrapyramidal symptoms associated with the use of thioridazine (Gould et al., 1984; Svendsen et al., 1988).

One specific side effect of thioridazine has found some therapeutic application. Thioridazine inhibits sperm emission in patients without affecting normal erection or the sensation of orgasm (Greenberg \& Carrillo, 1968; Kotin et al., 1976). This effect has been used to inhibit nocturnal emissions and control premature ejaculation (Clein, 1962; Singh, 1963). It was suggested by Gould et al. (1984) that this effect of thioridazine may be due to the blockade of smooth muscle $\mathrm{Ca}^{2+}$ channels. However, it has been reported that electrically induced responses of the human vas deferens are fairly insensitive to a variety of $\mathrm{Ca}^{2+}$ channel blockers (Fovaeus et al., 1987; Smith \& Bray, 1990). In an earlier study (Amobi \& Smith, 1991), we found that thioridazine did not affect contractions induced by caffeine or A23187, but induced some rhythmic contractions of the rat vas deferens. Thioridazine only partly inhibited responses to high potassium concentration. Thus, the role of $\mathrm{Ca}^{2+}$ in thioridazine-induced ejaculatory failure remains uncertain. Indeed, there are no reports on the effects of thioridazine on the response of the human vas deferens to its primary transmitter, noradrenaline (Anton \& McGrath, 1977; Ratnasooriya et al., 1979; Bellis et al., 1982;

${ }^{*}$ Corresponding author. 
Michailov et al., 1983; Hedlund et al., 1985). The present investigation studies directly the effects of thioridazine on the contraction of the human vas deferens induced by exogenous noradrenaline or high extracellular potassium.

\section{Materials and Methods}

\section{Tissues}

Human vasa deferentia were obtained from vasectomies of healthy fertile men. The specimens, 5-15 mm long, were taken from the epididymal portion of the vas deferens. They were placed in ice-cold Krebs' bicarbonate saline and experiments started 2-20 h later. No systematic effect of storage time was noted. Connective tissue and superficial blood vessels were removed using a light microscope $(\times 20)$. The tissues were suspended horizontally (resting tension, 0.5-1 g) in a jacketed Perspex chamber and superfused at $2.5 \mathrm{ml} \mathrm{min}^{-1}$ with warm Krebs' bicarbonate saline solution $\left(25 \mathrm{mmol} \mathrm{NaHCO}_{3} \mathrm{l}^{-1} ; 118.8 \mathrm{mmol} \mathrm{NaCl} l^{-1} ; 4.7 \mathrm{mmol} \mathrm{KCl} l^{-1} ; 2.5 \mathrm{mmol} \mathrm{CaCl}_{2} .2 \mathrm{H}_{2} \mathrm{Ol}^{-1} ; 1.2 \mathrm{mmol} \mathrm{KH}_{2} \mathrm{PO}_{4} \mathrm{I}^{-1}\right.$; $1.2 \mathrm{mmol} \mathrm{MgSO}_{4} .7 \mathrm{H}_{2} \mathrm{Ol}^{-1}, 11 \cdot 1 \mathrm{mmol}$ glucose $1^{-1}$ ) at $35 \cdot 8-36 \cdot 0{ }^{\circ} \mathrm{C}$ and with $95 \% \mathrm{O}_{2}$ and $5 \% \mathrm{CO}_{2}$. The preparations were allowed to equilibrate in Krebs' solution for 90-150 min before the experiments began.

\section{Mechanical recordings}

Records of isometric tension were made with a Washington type D tension transducer coupled to a Venture Servoscribe potentiometric recorder.

\section{Drug treatments}

Drugs used were phenoxybenzamine hydrochloride (Smith, Kline \& Beecham, Welwyn Garden City, Herts, UK), atropine sulfate (BDH Pharmaceuticals, London, UK), prazosin (Pfizer Ltd, Sandwich, Kent, UK), phentolamine mesylate (Ciba Laboratories, Horsham, Sussex, UK) and noradrenaline acid tartrate, propranolol hydrochloride, thioridazine hydrochloride, promazine hydrochloride, EGTA, choline chloride, tetrodotoxin, nifedipine, verapamil hydrochloride and diltiazem hydrochloride (Sigma: Poole, Dorset, UK). $\mathrm{Ca}^{2+}$-free solutions, prepared by isotonically replacing $\mathrm{CaCl}_{2}$ with $\mathrm{NaCl}$, contained EGTA $\left(0.5-1.0 \mathrm{mmol}^{-1}\right)$ and the calcium-channel blockers nifedipine $\left(10 \mu \mathrm{mol}^{-1}\right)$ and verapamil $\left(10 \mu \mathrm{mol} 1^{-1}\right)$. Isotonic potassium solutions were prepared by replacing $\mathrm{NaCl}$ with $\mathrm{KCl}$ and by partial replacement of $\mathrm{NaHCO}_{3}$ with $\mathrm{KHCO}_{3}$. Control solutions, prepared by the isotonic replacement of $\mathrm{NaCl}$ with $\mathrm{LiCl}$ or choline chloride with atropine $\left(10 \mu \mathrm{mol}^{-1}\right)$ did not cause contractions. Experiments with high potassium concentrations were carried out after equilibration for 60-90 min in Krebs' solution containing tetrodotoxin $\left(0 \cdot 1 \mu \mathrm{mol}{ }^{-1}\right)$ and guanethidine $\left.(10 \mu \mathrm{mol}]^{-1}\right)$, to block the activation of intramural nerves and the release of neurotransmitters. These solutions also contained either prazosin or the irreversible $\alpha$-adrenoceptor blocker phenoxybenzamine ( $10 \mu \mathrm{mol} \mathrm{I}^{-1}$; added $20-40 \mathrm{~min}$ before testing). In some experiments, the $\beta$-adrenoceptor blocker propranolol $\left(10 \mu \mathrm{mol} \mathrm{I}^{-1}\right)$ was also added.

\section{Analysis of results}

Response measurements refer to the maximal shortening or lengthening of the specimens but exclude bursts of phasic activity. Data are given as means \pm SEM and $n$ refers to the number of preparations. Statistical analysis was carried out using Student's $t$ test and, where appropriate, a one-way analysis of variance (ANOvA). A significant $F$ value from ANOVA tests with $P<0.05$ was followed by comparison of means using Tukey's honestly significant difference. Means of drug-free controls and experimental groups were considered significantly different at $P<0.05$ and highly significant at $P<0.01$.

\section{Results}

\section{Responses to noradrenaline in normal Krebs' media}

Responses to noradrenaline $\left(100 \mu \mathrm{mol}^{-1}\right)$ varied. In 17 of 76 preparations (e.g. Fig. la) there was an initial increase in tension of the tissue (referred to as the shortening response) followed by a decline to less than basal tensions (the lengthening response). In other preparations there was either a shortening ( $n=34$, Fig. 2 ) or a lengthening response $(n=25$, Fig. 6a). In all preparations, the responses were associated with bursts of phasic activity. Lower doses of noradrenaline $(1-10 \mu \mathrm{mol}$ $1^{-1}$ ) induced fewer bursts of phasic activity and relatively smaller lengthening responses. 
(a)

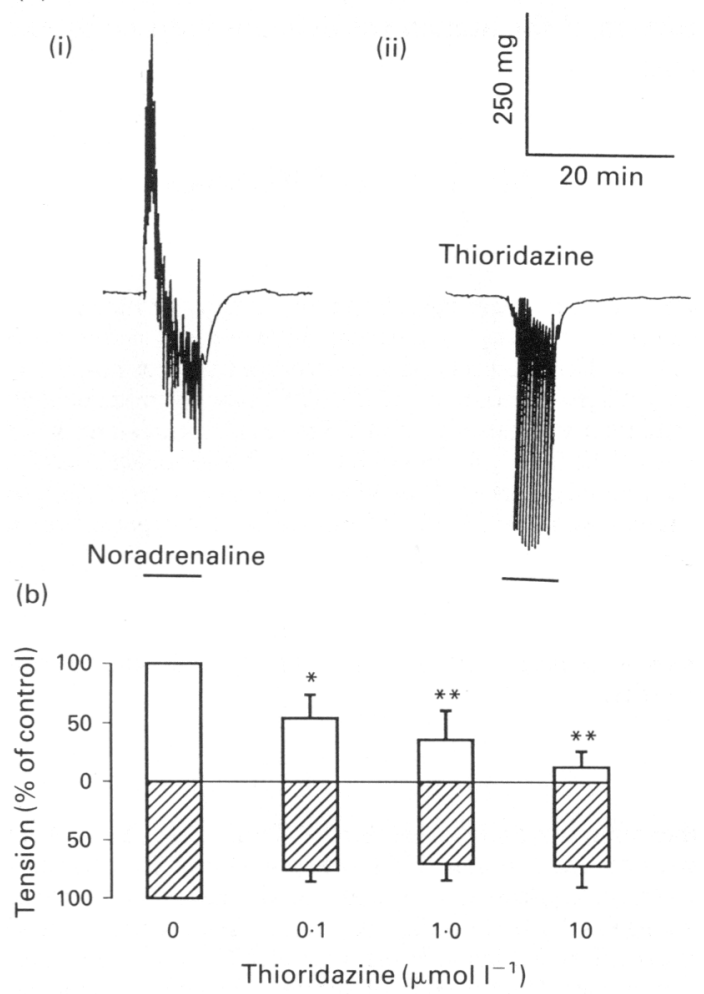

Fig. 1. Effects of thioridazine on the mechanical tension of the human vas deferens induced by noradrenaline. (a) (i) Record showing both shortening (upward) and lengthening (downward) response to noradrenaline $\left(100 \mu \mathrm{mol}^{-1}\right)$. (These reflect contractions of longitudinal and circular muscle respectively.) (ii) Inhibition of the shortening after exposure of this preparation to thioridazine $\left(1 \mu \mathrm{mol}^{-1}\right)$ for $40 \mathrm{~min}$. Horizontal lines show the period of exposure to noradrenaline. (b) Effects of thioridazine $\left(0 \cdot 1-10 \mu \mathrm{moll}^{-1}\right)$ on preparations that had exhibited either shortening (upward bars, $n=6$ ) or lengthening (downward bars, $n=9$ ) or both responses to noradrenaline $\left(100 \mu \mathrm{mol}^{-1}\right)$. Measurements are of peak underlying tonic tension and are expressed as a percentage of the corresponding drug-free value. Bars show means and vertical lines indicate SEM. Statistical significances $\left({ }^{*} P<0.05 ;{ }^{* *} P<0.01\right)$ are relative to the initial response. In control experiments the decrease that results from repeated exposure to noradrenaline was small ( $11 \pm 3 \%$ per exposure, $n=7)$.

Thioridazine $\left(0 \cdot 1-10 \mu \mathrm{mol} 1^{-1}\right)$ produced a dose-related reduction in both phasic and tonic shortening. The tonic lengthening remained relatively unchanged (Fig. 1). In some preparations $(n=4)$ thioridazine uncovered a previously unseen lengthening (Fig. 2). Bursts of phasic lengthening in response to noradrenaline were enhanced by thioridazine (Figs la and 2).

Exposure of the tissues to prazosin $(n=4)$ or phentolamine $(n=6)$ for up to $35 \mathrm{~min}$ at $1 \mu \mathrm{moll}{ }^{-1}$ significantly reduced and at $10 \mu \mathrm{mol} 1^{-1}$ blocked shortening and lengthening responses (Fig. 3a). Promazine $\left(10 \mu \mathrm{mol} 1^{-1}, n=3\right)$, a prototype phenothiazine, also blocked both responses to noradrenaline.

\section{Responses to high potassium concentration in normal Krebs' media}

High potassium concentration $\left(136 \mathrm{mmol}^{-1}\right)$ always elicited an initial shortening. In most preparations (20 of 29 ), this was followed by lengthening (Fig. 4a) which ranged from $30 \%$ to $300 \%$ of the initial shortening (see Figs 5 and 7c). In the other preparations high potassium 


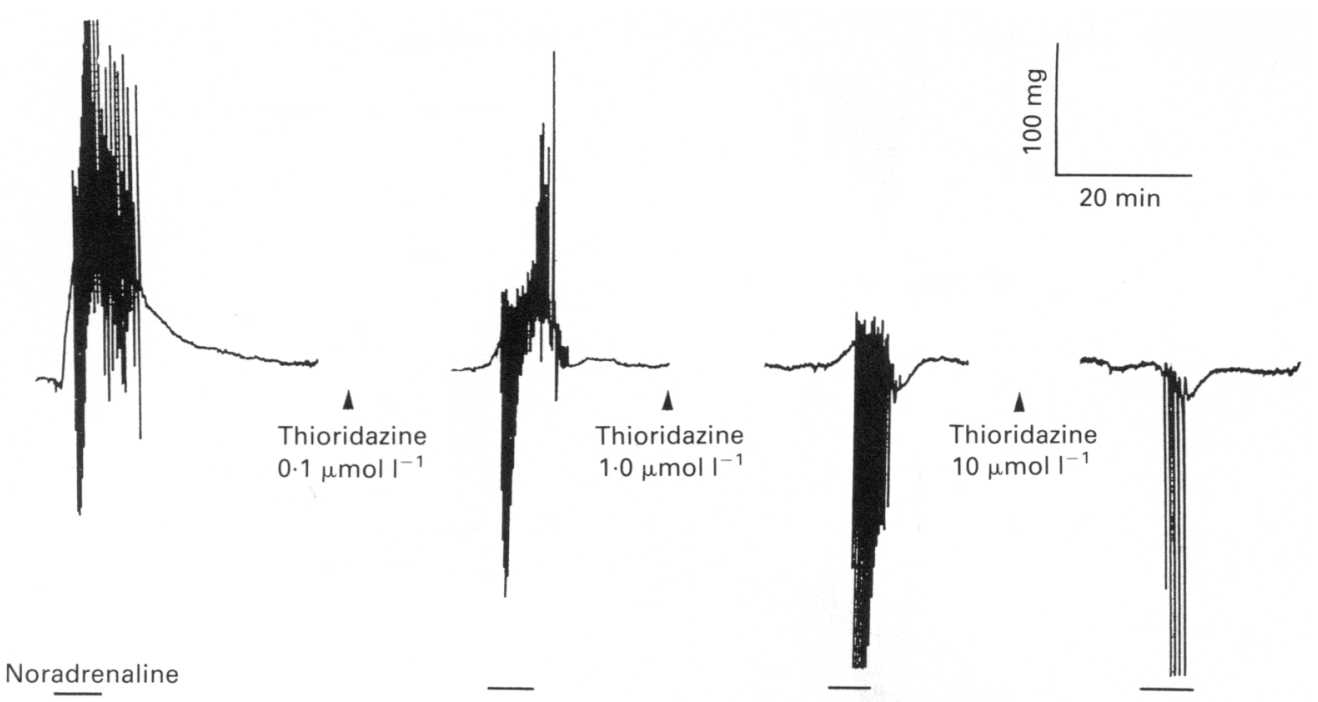

Fig. 2. Progressive effect of thioridazine $\left(0 \cdot 1-10 \mu \mathrm{mol} \mathrm{I}^{-1}\right)$ on the mechanical response induced by noradrenaline $\left(100 \mu \mathrm{mol} \mathrm{l}^{-1}\right)$ in a single preparation of human vas deferens. Inhibition of the shortening (upward) response was accompanied by the appearance of a lengthening (downward) component. The tissue was exposed to each dose of thioridazine for 40-50 min before application of noradrenaline. Horizontal lines indicate period of exposure to noradrenaline.

concentration elicited biphasic shortenings (not shown) where the secondary shortening measured $17-52 \%(32 \pm 13 \%, n=9)$ of the initial response. Occasionally ( 6 of 29$)$, high potassium concentration initially gave brief bursts of phasic activity. Thioridazine $\left(0 \cdot 1-10 \mu \mathrm{mol}^{-1}\right)$, added to tissues showing both shortening and lengthening responses, gave a dose-related reduction of the shortening without any significant change in the lengthening response (Fig. 4). These responses were recorded in the presence of the $\alpha$-adrenoceptor antagonists prazosin $\left(10 \mu \mathrm{mol} 1^{-1}\right)$ or phenoxybenzamine ( $10 \mu \mathrm{mol}^{-1}$; see methods), thus precluding the effects of noradrenaline release from the intramural nerves or the action of thioridazine on the post-junctional $\alpha$-adrenoceptors.

\section{Effects of $\mathrm{Ca}^{2+}$ channel antagonists}

Responses to high potassium concentration $\left(136 \mathrm{mmol} \mathrm{l}^{-1}\right.$, Fig. 5), which are assumed to depend on membrane depolarization and the entry of $\mathrm{Ca}^{2+}$ through voltage-gated channels, were almost abolished by diltiazem $\left(10 \mu \mathrm{moll}^{-1}\right)$ or verapamil $\left(10 \mu \mathrm{moll}^{-1}\right)$. With lower doses of diltiazem $\left(0 \cdot 1-1 \mu \mathrm{mol} \mathrm{l}^{-1}\right)$ there was no differential blockade of the shortening. Bursts of phasic activity induced by noradrenaline $\left(100 \mu \mathrm{mol}^{-1}\right)$ were abolished by verapamil $\left(10 \mu \mathrm{mol}^{-1}\right.$; Fig. $\left.6 \mathrm{a}\right)$, but were relatively insensitive to diltiazem (up to $10 \mu \mathrm{mol} 1^{-1}$; not shown). The shortening and lengthening responses induced by noradrenaline were significantly reduced by verapamil or diltiazem, though $11-40 \%$ of both responses remained (Figs $6 a$ and b). These remaining responses, especially the shortening, exhibited a biphasic profile which was not evident in the drug-free controls (Fig. 6a). The addition of nifedipine $\left(10 \mu \mathrm{mol} \mathrm{1}^{-1}\right)$ in the continued presence of either verapamil or diltiazem caused no further change in the size of the shortening or lengthening responses induced by noradrenaline (Fig. $6 \mathrm{a}-\mathrm{c}$ ). This range of effects produced by the $\mathrm{Ca}^{2+}$ antagonists differs markedly from that of thioridazine (see Figs 1 and 2).

\section{Responses in $\mathrm{Ca}^{2+}$-free media to noradrenaline or high potassium media}

After perfusion for 25-30 min in $\mathrm{Ca}^{2+}$-free media containing EGTA $\left(0 \cdot 5 \mathrm{mmol}^{-1}\right)$, verapamil and nifedipine, the responses to noradrenaline were reduced to $17 \cdot 5 \pm 12 \%(n=12)$ for the 


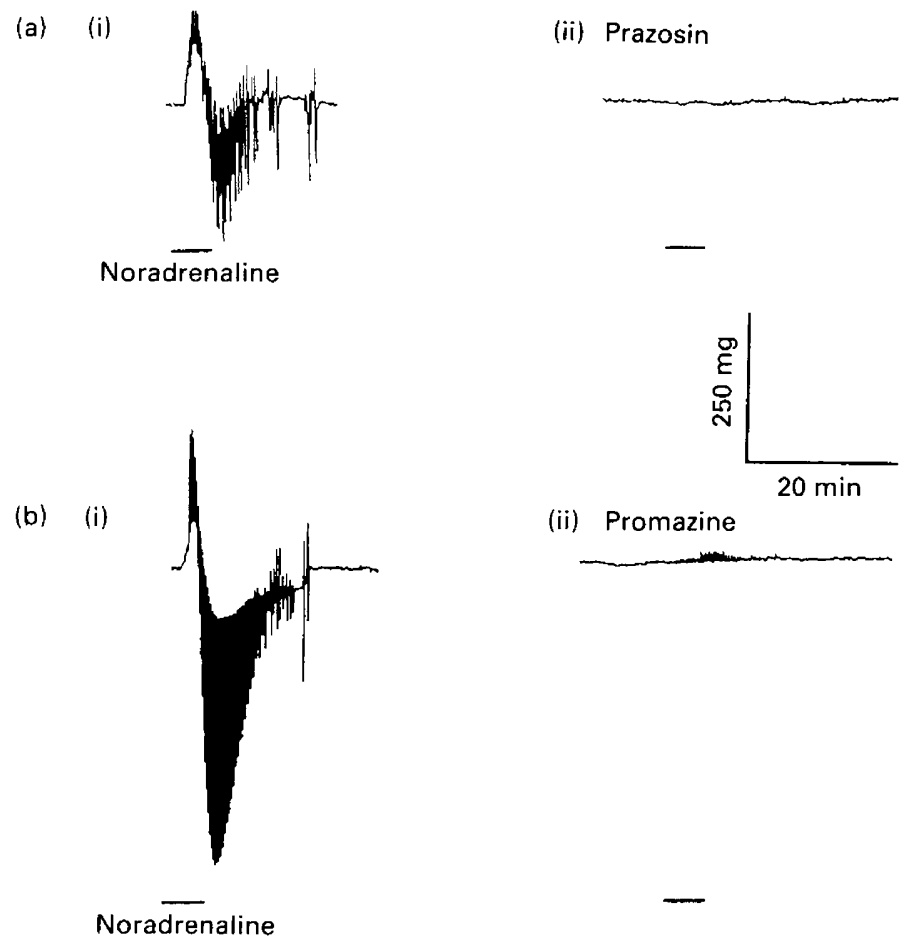

Fig. 3. Effects of the $\alpha$-adrenoceptor blocker, prazosin, and the phenothiazine, promazine, on the mechanical responses of different preparations of human vas deferens to noradrenaline. The drug-free controls (i) show both shortening (upwards) and lengthening (downwards) to noradrenaline $\left(100 \mu \mathrm{mol} \mathrm{l}^{-1}\right)$. Both responses were inhibited (ii) by (a) prazosin $\left(10 \mu \mathrm{mol}{ }^{-1}\right)$ and by (b) promazine $\left(10 \mu \mathrm{mol} \mathrm{l}^{-1}\right)$, applied 35-40 min before noradrenaline. Horizontal bars indicate period of exposure to noradrenaline.

shortening and to $29 \cdot 4 \pm 14 \%(n=11)$ for the lengthening of the corresponding response in Krebs' media (Fig. 7a and b). Phasic activity was abolished. These effects were fully reversed within 40-60 min of readmitting Ca ${ }^{2+}\left(2 \cdot 54 \mathrm{mmoll}^{-1}\right)$ in experiments where the $\mathrm{Ca}^{2+}$ antagonists had been omitted. Thioridazine $\left(0 \cdot 1-10 \mu \mathrm{moll}^{-1}\right)$ had effects on the $\mathrm{Ca}^{2+}$-free responses to noradrenaline that were similar to those observed in Krebs: it inhibited the shortening, but not the lengthening, responses (Fig. $7 \mathrm{~d}$ ).

Activation with high potassium concentration $\left(136 \mathrm{mmol}^{-1}\right)$, after exposure of the tissues for $30-40 \mathrm{~min}$ to $\mathrm{Ca}^{2+}$-free media containing EGTA $\left(0.5 \mathrm{mmol}^{-1}\right)$, nifedipine and verapamil, elicited small contractions which ranged from 5-21\% (mean $7 \cdot 4 \pm 5.9 \% ; n=5$ ) of the initial shortening response in Krebs' media (Fig. 7c). These were also recorded when the EGTA concentration was raised to $1 \mathrm{mmol} \mathrm{l}^{-1}$ (not shown). They were similar to the persistent response to high potassium concentration found to be resistant to the action of $\mathrm{Ca}^{2+}$ antagonists (see Fig. 5). Thioridazine $\left(0 \cdot 1-10 \mu \mathrm{mol}{ }^{-1}\right)$ caused a dose-related potentiation of the response to potassium in $\mathrm{Ca}^{2+}$-free media (Fig. 7c and d). This potentiation persisted after thioridazine was washed out for $30-40 \mathrm{~min}$.

\section{Discussion}

Variations in the pattern of response of human vas deferens to direct or indirect muscle stimulation or $\alpha$-adrenoceptor agonists have been reported by Anton \& McGrath (1977), Ratnasooriya et al. (1979) and Smith \& Bray (1990). The tissue gives both shortening and lengthening responses which 


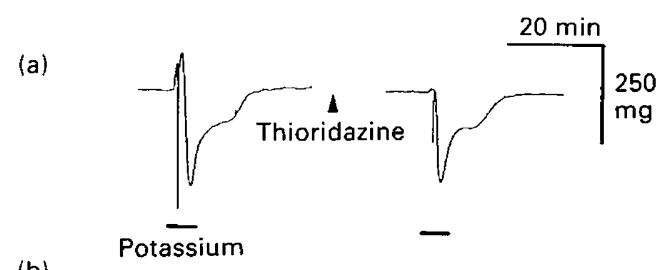

(b)

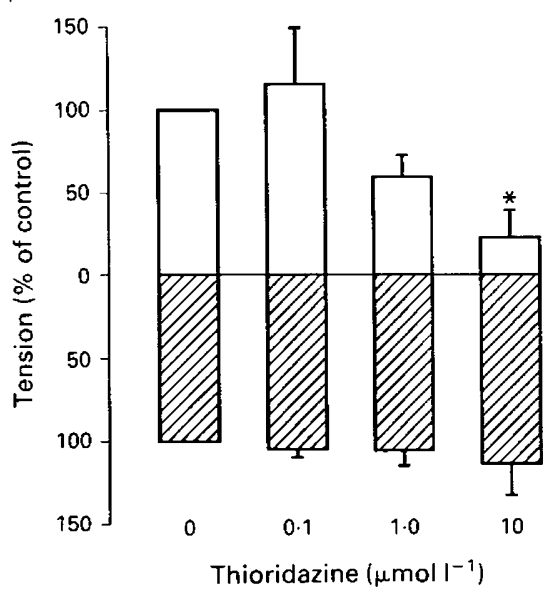

Fig. 4. Effects of thioridazine on the mechanical response of the human vas deferens to high potassium concentration $\left(136 \mathrm{mmol}^{-1}\right)$. (a) Records showing inhibition of the shortening (upward), but not the lengthening (downward) response induced by high potassium concentration after $40 \mathrm{~min}$ exposure to thioridazine $\left(10 \mu \mathrm{mol}^{-1}\right)$. Horizontal bar indicates period of exposure to potassium. (b) Average responses of nine preparations have both shortening (upward bars) and lengthening (downward bars) responses to high potassium concentration, after progressive concentrations of thioridazine $\left(0 \cdot 1-10 \mu \mathrm{moll}^{-1}\right) .\left({ }^{*} P<0 \cdot 05\right)$. The mean control lengthening was $86 \%$ of the control shortening.

have been ascribed to the contractions of the longitudinal and circular layers of smooth muscle, respectively (Anton \& McGrath, 1977; Smith \& Bray, 1990). We have observed that thioridazine blocked contractions of the longitudinal muscle, but not the circular muscle, of the human vas deferens. These effects were obtained with thioridazine at concentrations well within the therapeutic range (2-10 $\mu \mathrm{mol} \mathrm{l}^{-1}$; Murphy et al., 1983; Gould et al., 1984; Cohen et al., 1989), and may thus account for the clinical observations that thioridazine inhibits ejaculation in patients.

Thioridazine has been reported to have an action similar to that of the benzothiazepine $\mathrm{Ca}^{2+}$ antagonist, diltiazem (Murphy et al., 1983; Thorgeirsson \& Rudolph, 1984) and appears to bind to the verapamil site on the $\mathrm{Ca}^{2+}$-channel (Snyder \& Reynolds, 1985). It has thus been suggested (Gould et al., 1984), on the basis of receptor binding and pharmacological studies of rat vas deferens, that the inhibition of ejaculation by thioridazine may be due to the blockade of voltagegated $\mathrm{Ca}^{2+}$ channels. However, the human vas deferens differs from that of rats in several respects (Birmingham, 1968; Anton \& McGrath, 1977; Smith \& Bray, 1990). In the present study we found that the effects of thioridazine on the human vas deferens were not matched by diltiazem or verapamil. The lengthening response remained relatively unchanged while the shortening was markedly inhibited or abolished by thioridazine. In contrast, the $\mathrm{Ca}^{2+}$ antagonists reduced both components of the responses. Moreover, in the presence of high doses of diltiazem or verapamil, the residual shortening response to noradrenaline exhibited a biphasic profile; this effect was not observed in the presence of thioridazine.

The persistence of lengthening responses in the presence of thioridazine may be explained by several mechanisms. Thioridazine may penetrate poorly through the tissue because of diffusional 
(a)

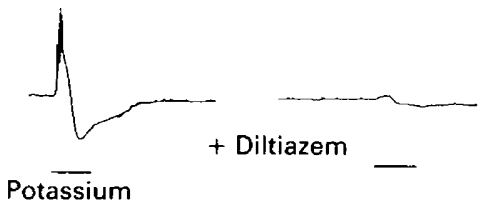

(b)
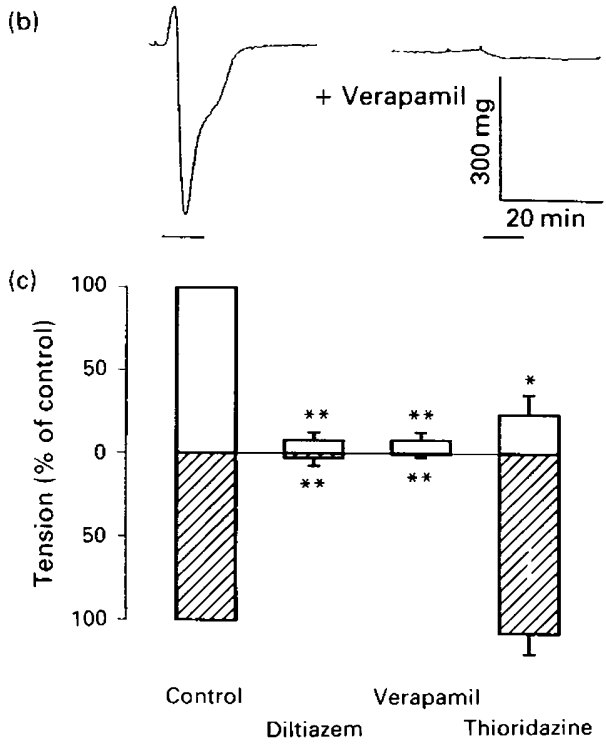

Fig. 5. Effects of calcium antagonists on the response of human vas deferens to high potassium concentration. Records were obtained before and 35-40 min after addition of (a) diltiazem $\left(10 \mu \mathrm{mol}^{-1}\right)$, and (b) verapamil $\left(10 \mu \mathrm{mol} \mathrm{l}^{-1}\right)$. Horizontal bar indicates period of exposure to potassium. In (c) these effects are compared with those of thioridazine $\left(10 \mu \mathrm{moll}^{-1}\right.$ (from Fig. 4)). Bars show shortening (upward) and lengthening (downward) responses in the presence of diltiazem $(n=4)$, verapamil $(n=5)$ and thioridazine $(n=9)$. Data are expressed as a percentage of the corresponding component in the drug-free control $\left({ }^{*} P<0.05 ;{ }^{* *} P<0.01\right)$.

restrictions and thus may not achieve the concentration necessary to block the contraction of the circular smooth muscle layer. Thioridazine may be a less potent $\mathrm{Ca}^{2+}$ antagonist than verapamil or diltiazem. However, these explanations seem unlikely, as the effects of thioridazine were not matched by the actions of low doses of diltiazem. Thus, either the circular muscle exhibits thioridazineinsensitive $\mathrm{Ca}^{2+}$ channels, or the action of thioridazine depends on some other mechanism.

The inhibition by thioridazine of the shortening response induced by noradrenaline does not appear to be caused by the blockade of $\alpha$-adrenoceptors. This selective action was not replicated by the more conventional $\alpha$-adrenoceptor blockers, prazosin or phentolamine, or by the prototype phenothiazine, promazine, which reportedly displays an $\alpha$-adrenoceptor blocking action similar to that of thioridazine (Peroutka \& Snyder, 1980). These drugs abolished both shortening and lengthening responses to noradrenaline. A differential effect could exist if the lengthening response involved the activation of an $\alpha_{1}$-adrenoceptor subtype (Han et al., 1987) not susceptible to blockade by thioridazine. Nevertheless, the possibility that thioridazine may elicit effects other than the blockade of $\alpha_{1}$-adrenoceptors or voltage-gated $\mathrm{Ca}^{2+}$ channels is apparent from the finding that the response to potassium in $\mathrm{Ca}^{2+}$-free media was enhanced by thioridazine.

Smooth muscle may be activated through electro- or pharmaco-mechanical coupling (Somlyo \& Somlyo, 1968; Droogmans et al., 1977; Trapani et al., 1981). Thus part of the response of the human vas deferens to noradrenaline is not blocked by $\mathrm{Ca}^{2+}$ antagonists or $\mathrm{Ca}^{2+}$-free media and presumably depends on intracellular calcium stores (Fovaeus et al., 1987; Smith \& Bray, 1990). It is 


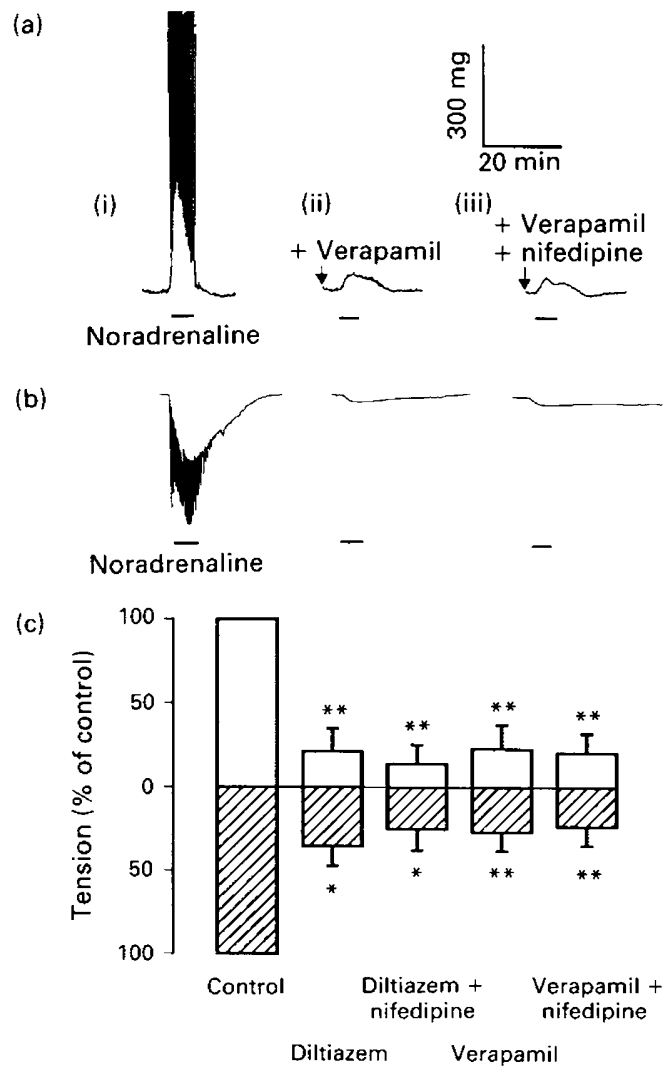

Fig. 6. Effects of the calcium antagonists on mechanical responses of human vas deferens to noradrenaline $\left(100 \mu \mathrm{moll}^{-1}\right)$. Different preparations show (a) shortening (upward) and (b) lengthening (downward) responses. Records show drug-free controls, the inhibitory effects of verapamil $\left(10 \mu \mathrm{moll}^{-1}\right)$ and the additional effect of nifedipine $\left(10 \mu \mathrm{mol} 1^{-1}\right)$. Horizontal bars indicate duration of exposure to noradrenaline. Drug contact time 40-45 min. (c) Bars give means from preparations showing shortening (upward, $n=8$ ) or lengthening (downward, $n=5$ ) responses. The calcium antagonists inhibited both types of response. Vertical lines give $\operatorname{SEM}\left({ }^{*} P<0.05 ;{ }^{* *} P<0.01\right)$.

conventionally assumed that electrical coupling depends on $\mathrm{Ca}^{2+}$ entry. However, depolarizing agents have been reported to elicit smooth muscle contraction in $\mathrm{Ca}^{2+}$-free media (Mangel et al., 1982; Mangel, 1984; Amobi \& Smith, 1990) which may involve the release of intracellular $\mathrm{Ca}^{2+}$ (Khoyi et al., 1989). We have suggested that this is associated with the activation of a calmodulinindependent mechanism of tension production (Amobi \& Smith, 1990, 1991). We therefore examined the effects of thioridazine on the responses of human vas deferens in $\mathrm{Ca}^{2+}$-free media. We have reported previously that contractions produced by agents that released intracellular $\mathrm{Ca}^{2+}$ such as caffeine or A23187 were unaffected by thioridazine (Amobi \& Smith, 1991). This observation suggests that thioridazine may elicit its effect early in the pathway linking membrane activation to response. Two pharmacological actions of phenothiazines that may be relevant to this include the ability to displace membrane-bound $\mathrm{Ca}^{2+}$ (Kwant \& Seeman, 1969; Brostrom et al., 1978) and the inhibition of calmodulin-dependent processes (Janis et al., 1987; Beitner et al., 1989). Thioridazine may potentiate electromechanical responses in $\mathrm{Ca}^{2+}$-free media through the displacement of membrane-bound $\mathrm{Ca}^{2+}$ or by reduction of $\mathrm{Ca}^{2+}$ extrusion consequent to inhibition of the calmodulin-activated sarcolemmal $\mathrm{Ca}^{2+}$ pump. 
Krebs' $\mathrm{Ca}^{2+}$-free $\mathrm{Ca}^{2+}$-free media

media media + thioridazine

(a)

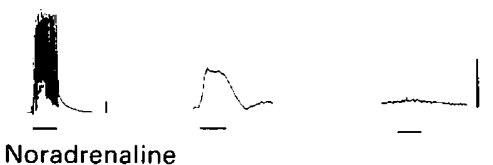

(b)

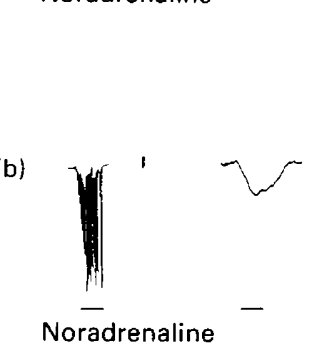

(c)
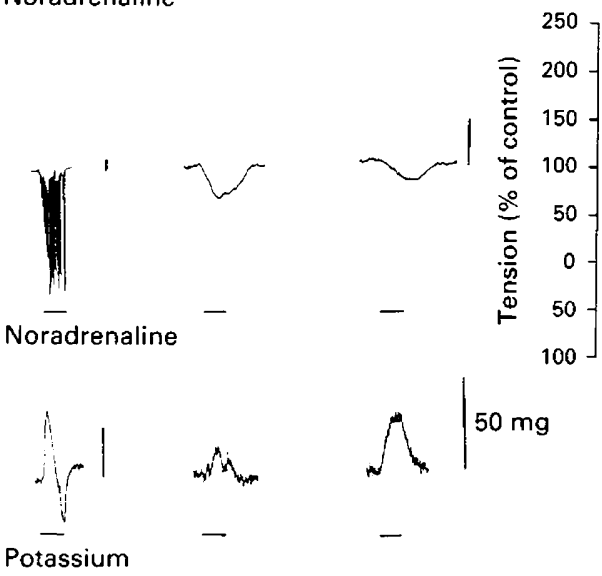

(d)
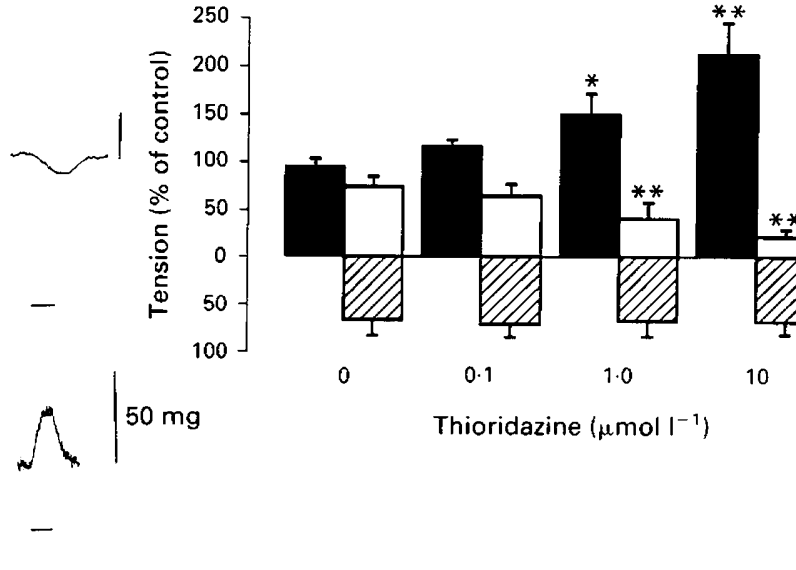

$$
\overline{40 \mathrm{~min}}
$$

Fig. 7. Effects of thioridazine on mechanical responses of human vas deferens in calcium-free media to noradrenaline and high potassium concentration. Preparations show (a) shortening, (b) lengthening responses induced by noradrenaline $\left(100 \mu \mathrm{moll}^{-1}\right)$ and (c) both responses induced by high potassium concentration $\left(136 \mathrm{mmoll}^{-1}\right)$. Records were obtained in normal Krebs' medium, calcium-free media $\left(0.5 \mathrm{mmol}^{-1}\right.$ EGTA) and after $30-40 \mathrm{~min}$ exposure to thioridazine $\left(10 \mu \mathrm{mol}^{-1}\right)$ in calcium-free media. Horizontal bars indicate duration of exposure to noradrenaline (a and b) and potassium (c). (d) Summary of the effects of thioridazine $(0 \cdot 1-$ $10 \mu \mathrm{moll}^{-1}$ ) on shortening (upward bars) and lengthening (downward bars) responses induced by noradrenaline (open bars) and on the shortening to high potassium concentration (solid bars). Repeated stimulation in calcium-free media produced a partial decrease, especially of the lengthening responses. This has been allowed for by expressing the data as the mean of the second and third calcium-free response relative to the first. Thioridazine was added after the first calcium-free response except for the control experiments. Bars represent the mean of peak tonic responses and lines the SEM from $4-7$ preparations $\left({ }^{*} P<0 \cdot 05 ;{ }^{*} P<0 \cdot 01\right)$.

The results of this study show that the effects of thioridazine on the responses induced by noradrenaline or potassium in the human vas deferens are not matched by those of diltiazem or verapamil. Consequently, its inhibitory action on the contraction of the tissue may not be accounted for entirely by its binding to the verapamil site and blockade of $\mathrm{Ca}^{2+}$ channels. The selective blockade of longitudinal muscle by thioridazine may explain its ability to specifically inhibit sperm emission in patients, as the remaining contraction of the circular muscle could block the propulsion of sperm along the vas deferens.

We thank J. Pryor and the King's College Hospital, London, for the supply of tissues and King's College London for financial support.

\section{References}

Amobi, N.I.B. \& Smith, I.C.H. (1990) Evidence for depolarization-induced responses of isolated human and rat vasa deferentia in $\mathrm{Ca}^{2+}$-free media. Journal of Physiology 423, 58P.
Amobi, N.I.B. \& Smith, I.C.H. (1991) Paradoxical effects of thioridazine on electromechanical coupling in the human and rat vas deferens. European Journal of Pharmacology 192, 343-348.

Downloaded from Bioscientifica.com at 04/26/2023 11:53:09AM 
Anton, P.G. \& McGrath, J.C. (1977) Further evidence for adrenergic transmission in the human vas deferens. Journal of Physiology 273, 45-55.

Beitner, R., Chenzion, M., Benporat, H., Morgenstern, $\mathbf{H}$. \& Soferbassukevitz, Y. (1989) Treatment of frostbite with the calmodulin antagonists thioridazine and trifluoperazine. General Pharmacology 20, 641-646.

Bellis, J.A., Colby, J.E. \& Westfall, D.P. (1982) Effects of $\alpha$-adrenoceptor agents on norepinephrine release from several species including man. European Journal of Pharmacology 78, 487-490.

Birmingham, A.T. (1968) The human isolated vas deferens: its response to electrical stimulation and to drugs. British Journal of Pharmacology 34, 692P.

Brostrom, M.A., Brostrom, C.O., Breckenridge, B. McL. \& Wolff, D.J. (1978) Calcium-dependent regulation of brain adenylate cyclase. Advances in Cyclic Nucleotide Research 9, 85-99.

Clein, L. (1962) Thioridazine and ejaculation. British Medical Bulletin 2, 548-549.

Cohen, B.M., Lipinski, J.F. \& Waternaux, C. (1989) A fixed dose study of the plasma concentration and clinical effects of thioridazine and its major metabolites. Psychopharmacology 97, 481-488.

Creese, I., Burt, D.R. \& Snyder, S.A. (1976) Dopamine receptor binding predicts clinical and pharmacological potencies of antischizophrenic drugs. Science, $N Y$ 192, $481-483$.

Droogmans, G., Raeymaekers, L. \& Casteels, R. (1977) Electro- and pharmaco-mechanical coupling in the smooth muscle cells of the rabbit ear artery. Journal of General Physiology 70, 129-148.

Fovaeus, M., Andersson, K.-E. \& Hedlund, H. (1987) Calcium channel blockade and contractile responses in the isolated human vas deferens. Journal of Urology 138, 654-658.

Gould, R.J., Murphy, M.M., Reynolds, I.J. \& Snyder, H. (1984) Calcium channel blockade: possible explanation for thioridazine's peripheral side effects. American Journal of Psychiatry 141, 352-357.

Greenberg, H.R. \& Carrillo, C. (1968) Thioridazineinduced inhibition of masturbatory ejaculation in an adolescent. American Journal of Psychiatry 124, $991-993$.

Han, C., Abel, P.W. \& Minneman, K. (1987) $\alpha_{1}$ Adrenoceptor subtypes linked to different mechanisms for increasing intracellular $\mathrm{Ca}^{2+}$ in smooth muscle. Nature 329, 333-335.

Hediund, H., Andersson, K.-E. \& Larsson, B. (1985) Effects of drugs interacting with adrenoceptors and muscarinic receptors in the epididymal and prostatic parts of the human isolated vas deferens. Journal of Autonomic Pharmacology 5, 261-270.

Janis, R.A., Silver, P.J. \& Triggle, D.J. (1987) Drug action and cellular calcium regulation. Advances in Drug Research 16, 309-591.

Khoyi, M.A., Smith, M.A., Buxton, I.L.O. \& Westfall, D.P. (1989) Factors involved in the generation of tension during contraction to high potassium in the rat vas deferens. Cellular Signalling 1, 599-605.

Kotin, J., Wilbert, D.E., Verburg, D. \& Soldinger, S.M. (1976) Thioridazine and sexual dysfunction. American Journal of Psychiatry 133, 82-85.
Kwant, W.V. \& Seeman, P. (1969) The displacement of membrane calcium by a local anaesthetic (chlorpromazine). Biochimica et Biophysica Acta 193, 338-349.

Mangel, A.W. (1984) Voltage and receptor mediated contractile activity of colonic smooth muscle in calciumfree solution. European Journal of Pharmacology 102, $165-168$.

Mangel, A.W., Nelson, D.V., Rabovsky, J.L., Prosser, C.L. \& Connor, J.A. (1982) Depolarization-induced contractile activity of smooth muscle in calciumfree solution. American Journal of Physiology 242, C36-C40.

Michailov, M.C., Murray, A.B., Zettler, F. \& GrindlerGreimel, H. (1983) Differences in the physiological response and ultrastructure of human and guinea pig vas deferens. Urologia Internationalis 38, 234-242.

Murphy, K.M.M., Gould, R.J., Largent, B.L. \& Snyder, S.H. (1983) A unitary mechanism of calcium antagonist drug action. Proceedings of the National Academy of Science of the USA 80, 860-864.

Peroutka, S.J. \& Snyder, S.H. (1980) Relationship of neuroleptic drug effects at brain dopamine, serotonin, $\alpha$-adrenergic, and histamine receptors. American Journal of Psychiatry 137, 1518-1522.

Ratnasooriya, W.D., Wadsworth, R.M. \& Gilmore, D.P. (1979) The effect of sympathomimetic drugs on contractility of the vas deferens in vitro and in vivo. Journal of Reproduction and Fertility 56, 633-641.

Singh, H. (1963) Therapeutic use of thioridazine in premature ejaculation. American Journal of Psychiatry 119,891 .

Smith, I.C.H. \& Bray, M. (1990) Direct and indirect contractile responses of the human vas deferens and actions of noradrenaline and of calcium antagonists. Experimental Physiology 75, 33-43.

Snyder, S.H. \& Reynolds, I.J. (1985) Calcium-antagonist drugs. Receptor interactions that clarify therapeutic effects. New England Journal of Medicine 313, 995-1002.

Somlyo, A.V. \& Somlyo, A.P. (1968) Electromechanical and pharmacomechanical coupling in vascular smooth muscle. Journal of Pharmacology and Experimental Therapeutics 159, 129-145.

Svendsen, C.N., Froimwitz, M., Hrbek, C., Campbell, A., Kula, N., Baldessarini, R.J., Cohen, B.M., Babb, S., Teicher, M.H. \& Bird, E.D. (1988) Receptor affinity, neurochemistry and behavioural characteristics of enantiomers of thioridazine: Evidence for different stereoselectivities at $D_{1}$ and $D_{2}$ receptors in rat brain. Neuropharmacology 27, 1117-1124.

Thorgeirsson, G. \& Rudolph, S.A. (1984) Diltiazem-like effect of thioridazine on dihydropyridine binding site of calcium channel of rat myocardial membranes. Biochemical and Biophysics Research Communications 121, 657-663.

Trapani, A., Matsuki, N., Abel, P.W. \& Hermsmeyer, K. (1981) Norepinephrine produces tension through electromechanical coupling in rabbit ear artery. European Journal of Pharmacology 72, 87-91.

Received 8 July 1991 